\title{
Seppo Kontiainen
}

\section{Aikuinen ja koulutusyhteiskunta1)}

\begin{abstract}
Kontiainen, Seppo. 1984. Aikuinen ja koulutusyhteiskunta. Aikuiskasvatus 4, 1, 4-7. - Artikkeli on katsaus aikuisuuden, koulutuksen ja yhteiskunnan välisiin suhteisiin. Artikkelissa tarkastellaan ihmisen elämänkaarta ja työelämän muutosta erityisesti teknologisen kehityksen antamien haasteiden pohjalta. Elinikäisen oppimisen viitekehyksessä yhdistetään korkea-asteen opetus ja tutkimus aikuiskasvatukseen.
\end{abstract}

Yhteiskunnassa on vielä teollisessa kehitysvaiheessa voitu kuvitella, että nuoret työskenneltyään ahkerasti koulussa ja myöhemmin ammatillisessa koulutuksessa, sijoittuvat omaa suorituskykyään parhaiten vastaavalle tasolle, tekevät henkilökohtaiset ja uraansa koskevat päätökset oikein ja siitä eteenpäin elävät onnellista ja hyödyllistä elämää.

Mm. lisääntyvän työttömyyden myötä yhä useammat aikuiset joutuvat kuitenkin toistuvasti arvioimaan uudelleen elämäänsä. Pelkkä aikuisuuteen valmistava koulutus ja yksilön kypsyminen ottamaan vastaan aikuisen erilaiset roolit yhteiskunnassa ei enää riitä: moni palaa koulutukseen $\mathrm{mm}$. nopean teknologisen kehityksen vuoksi.

Niin kauan kun yhteiskunta ja työelämä ovat jatkuvassa dynaamisessa muutoksessa ja niin kauan kun ihmiset tekevät virheelliseksi osoittautuvia itseään koskevia ratkaisuja tai kehittyvät ja orientoituvat uudella tavalla iän myötä, tarvitaan aikuiskasvatusta ja -koulutusta.

\section{Aikuiskasvatus ja aikuiskoulutus}

Aikuiskasvatus viittaa mielestäni ensisijaisesti aikuisen omaehtoiseen itsensä kehittämiseen. Tähän kasvuun on erityisesti vapaan sivistystyön kenttä tarjonnut maassamme mahdollisuuksia.

Aikuiskoulutus on laajemman aikuiskasvatuksen osa-alue, joka on haluttu nähdä kytkeytyneenä erityisesti aikuisen ammatilliseen kehitykseen. Koulutus voidaan silloin nähdä osana yhteiskunnan säätelemää jatkuvan koulutuksen periaatteella toteutuvaa koulutusjärjestelmää.

1)Artikkeli perustuu Seppo Kontiaisen 30.11.1983 pitämään virkaanastujaisesitelmään.
Tähän saakka aikuinen on voinut käyttää koulutuspalveluja paljolti oman harkintansa mukaan. Työelämän ja yhteiskunnan muutokset ovat kuitenkin johtamassa siihen, että ammatillisesta aikuiskoulutuksesta on tulossa oppivelvollisuuden jatke.

\section{Aikuinen}

Kuka sitten on meidän yhteiskunnassamme aikuinen: virallisesti 18 vuotta täyttänyt henkilö. Käytännössä emme kuitenkaan tunnusta aikuiseksi kaikkia tämän ikävaiheen saavuttaneita. Aikuisuutta arvioidaan paljolti sen mukaan, mikä on ihmisen suhde työelämään. Työelämässä toimiva 18-vuotias on kielenkäytössämme aikuisempi kuin 24-vuotias yliopiston opiskelija. Toisaalta työelämästä syrjässä oleville on vakiintunut työsidonnaisia nimityksiä. Esimerkiksi työikäisestä ja -kuntoisesta aikuisesta on tullut työtön ja aktiivin työvaiheen sivuuttaneesta aikuisesta eläkeläinen. Aikuisen asemaa joudutaan jatkossa arvioimaan ehkä hyvinkin toisella tavalla, koska ihmisen suhde työhön on muuttumassa.

\section{Tyӧ ja toiminta}

Ritchie-Calder tarkastelee koulutuksen merkitystä siirryttäessä teollisesta yhteiskunnasta jälkiteolliseen yhteiskuntaan (Costello \& Richardson 1982, 11-21) seuraavasti: Teknologinen kehitys etenee jääväämättömäksi. Mikäli ihminen ei hallitse muuttuvaa todellisuutta, hänestä on vaarassa tulla automaatioprosessin inhimillinen, mutta entistä tarpeettomampi välikappale. Tämän teknologisen prosessin osana ihmisestä on joissakin yhteyksissä käytetty kärjistyneesti nimeä "'human cassette" _- 'ihmiskasetti", automaation ohjelmoitu osa. 
Viimeaikainen keskustelu myös meillä yhteiskunnan muuttumisesta tietoyhteiskunnaksi on tuonut esille erityisesti tiedon hyväksikäytön tuotannon ja taloudellisen hyvinvoinnin välineenä. Tietoyhteiskunnan taloudellisen hyvinvoinnin välineenä. Tietoyhteiskunnan taloudellisen hyvinvoinnin avulla voidaan ja on myös syytä pyrkiä kulttuuriyhteiskuntaan, joka turvaa yhteiskunnan jäsenten henkisen kasvun ja hyvinvoinnin. Työelämän kehitys ei välttämättä kauttaaltaan tule olemaan kovin suoraviivaista. Tietoyhteiskunnalla saattaa olla varaa hyväksyä mukaan myös pehmeän teknologian muotoja nostamalla esimerkiksi käsityöammatit uuteen nousuun. Eikä ruumiillinen työkään kokonaan hetkessä katoa. Vaikutukset näkyvät nyt selvimmin työvoimavaltaisilla teollisuusaloilla.

Siitä lähtien kun keksittiin vipu, ratas ja väkipyörä, ihminen on pyrkinyt ruumiillisen voiman vähentämiseen työssä. Teollinen vallankumous muutti käsityötaidot massatuotantotekniikoiksi. Se ei kuitenkaan lisännyt työntekijöiden vapaa-aikaa: se lisäsi tuotantoa. Tänään koneet eivät vähennä vain ruumiillista työtä, vaan pyrkivät huolehtimaan myös muista toiminnoista: myös 'ajattelusta', päättelyn ja päätöksenteon muodossa.

Antiikin Kreikassa työnjako oli selvä: orjat tekivät ruumiillisen työn, käsityöläinen antoi taitonsa yhteiskunnan palvelukseen ja filosofialla oli aikaa ajatella. - Vanhat määritelmät työstä ja sen luonteesta eivät enää pidä paikkaansa. Jos tietoyhteiskunnan näkökulmasta tarkastellaan ihmisen tulevaisuutta, niin yhä useampi vapautuu orjan ja käsityöläisen tehtävistä ja yhä useammalla olisi mahdollisuus asettua filosofin rooliin. Tästä mahdollisuudesta käytetään nykyään myös nimitystä työttömyys.

Tämän päivän aikuinen sukupolvi elää vielä voimakkaasti teollisen yhteiskunnan arvojen ja normien mukaan. Tieteen ja teknologian kehitys antavat mahdollisuuden vapauttaa ihminen työn sidonnaisuudesta perinteisessä mielessä uuteen toimintaan ja elämäntapaan. Olemme. tottuneet pitämään työnteon vastakohtana työttömyyttä. Tulevaisuudessa, jos yhteiskunta kehittyy edellä kuvattuun suuntaan, puhutaan ehkä työstä käsitteellä tekeminen ja toiminta ja työttömyys kuvataan käsitteellä toimettomuus.

Tekeminen ja toiminta antavat mahdollisuuden suuntautua työelämään perinteisessä mielessä, antiikin kreikkalaisen työnjaon mukai- sesti orjan, käsityöläisen ja filosofin rooleihin. Tekeminen ja toiminta on ihmisen aktiivista toimintaa - toimettomuus on passiivista, esimerkiksi viihdeteollisuuden ohjaamaa elämäntapaa.

Olemme tottuneet puhumaan työn etiikasta, mutta yhtä tärkeää olisi tällä hetkellä hahmottaa myös tekemisen ja toiminnan etiikka. Työtön ihminen on menettänyt usein itsekunnioituksensa ja täten myös toimintakykynsä: tämä on yhteiskunnan kehityksen näkökulmasta sekä varoitus että vaativa haaste. Haasteeseen tulisi myös korkeakoululaitoksen vastata omalta osaltaan.

Käsittääkseni yhteiskunnan ja yksilön aseman rajuissakin muutoksissa tulisi turvata ihminen, inhimillisen toiminnan perusyksikkönä, toimimaan itseään hallitsevasti. Tämä edellyttää, että hänellä on mahdollisimman hyvät tiedolliset ja taidolliset valmiudet ja kyky ymmärtää itseään ja ympäristöään muuttuvissa olosuhteissa. Oppimisen näkökulmasta (esim. Mezirow 1981) on tärkeää, että aikuinen pystyy rakentamaan kuvaa ympäröivästä todellisuudestaan, ei pelkästään tulkitsemalla subjektiivisia arkikokemuksiaan, vaan hahmottamalla toimintaansa sääteleviä keskeisiä tekijöitä. Arkikokemusten liittäminen laajempaan tietoon ja niiden ymmärtäminen esim. teorian tasolla edellyttää koulutusyhteiskunnalta varsin paljon.

Siirtyminen tietoyhteiskuntaan ei merkitse, etä ihminen työn luonteen muuttuessa jäisi pelkästään ajattelijaksi. Jos työn rinnakkaiskäsitteeksi hyväksytään toiminta sallii se edelleen ihmisten laaja-alaisen suuntautuneisuuden erilaisiin tehtäviin. Olennaista ehkä on se, ettei tekemistä ja sen mielekkyyttä mitata yksipuolisesti perinteisten työnormien ja -arvojen mukaan.

\section{Ikä ja vanheneminen}

Elinikäisen kasvatuksen periaatteen myötä on alettu hahmottaa ihmisen kehitystä elämänkaaren mukaan. Aikuisiän kehitysvaiheiden tutkimus on johtanut tarkastelemaan mm. vanhenemista uudesta näkökulmasta. Ihmisten keski-ikä on jatkuvasti kohonnut ja aktiivinen elämänvaihe on useilla varsin pitkä työiän jälkeen. Koska ihmistä, erityisesti koulutuksen näkökulmasta, punnitaan hänen osallistumisellaan työelämään, vanhuutta tavoitteleva sukupolvi jätetään helposti syrjään.

Jos jälkiteollisen yhteiskunnan uusi työn käsite otetaan vakavasti, niin työelämästä syrjässä oleva aikuinen saa myös uuden aseman. Liian usein nyt työelämästä pois siirtyvä tuntee it- 
sensä tarpeettomaksi, oman panoksensa jo antaneeksi luopujaksi.

Iäkäskin aikuinen voi olla aktiivinen, toimiva henkilö. Fyysisiä ponnistuksia vaativat tehtävät eivät enää ole hänen varmimpia alueitaan, luovuus ja taidot omarytmiseen toimintaan riittävät useimmiten (vrt. käsityöläinen); tätä on liikaakin pyritty korostamaan esim. askartelun ja puuhailun nimissä. Iäkäs aikuinen sopisi mielestäni hyvin filosofian, ajattelijan rooliin, ts. hänelle tulisi tarjota mahdollisuus saada liittää omaa elämänkokemustaan uuteen tietoon. Tämä tarve on oivallettu $\mathrm{mm}$. eräissä Ranskan, Saksan liittotasavallan ja Englannin yliopistoissa, joiden ovẹt on avattu ns. kolmannen sukupolven opiskelijoille.

Teollinen yhteiskunta on sysännyt työelämästä siirtyneen ihmisen karsaasti syrjään, uusi yhteiskunta voi parhaassa tapauksessa palauttaa iäkkäälle aikuiselle viisaan vanhuksen roolin.

Mielestäni on hälyyttävää, kun työelämästä siirtyvä aikuinen, vähän yli 60-vuotiaana, joutuu sairauksilla keräämään tositteita ennenaikaisen vanhuutensa tueksi. Sairaus on kuitenkin lähes ainoa aikuisen ominaisuus, johon yhteiskunta tuossa elämänvaiheessa reagoi.

\section{Tietoteknologia ja koulutus}

Englannin Open Universityn opetusteknologian professori David Hawkridge on vastikään ilmestyneessä teoksessaan (Hawkridge 1983) käsitellyt uuden tietoteknologian vaikutuksia kasvatukseen ja koulutukseen. Hawkridge määrittelee uuden tietoteknologian '.teknologiaksi, jota voidaan käyttää informaation luomiseen, varastointiin, valintaan, siirtämiseen ja jakeluun'. Kasvatus ja koulutus eivät ole kuitenkaan pelkkää tietoa ja tiedon siirtoa. Kasvatuksen olennainen piirre on sen riippuvuus inhimillisestä vuorovaikutuksesta. Ilman teknologiaa me toimimme esimerkiksi kuulo-, näkö- ja kosketushavaintojemme varassa. Teknologia vain laajentaa aistejamme.

Perinteisten radion, television ja puhelimen lisäksi aistejamme laajentavat nyt ja vielä enemmän tulevaisuudessa mikrotietokoneet, videolaitteet jne.

Tietoteknologia suuntaa opiskelijaa käyttämään runsaasti aikaa näyttöpäätteiden ääressä. Hän voi ottaa yhteyden video- ja ääniarkistoihin, kirjoihin tai aikakauslehtiin, hän voi katsella opetusfilmejä, selata taidekokoelmia, tutkia tietosanakirjoja, hankkia ajan tasalla olevia tilastotietoja, selvittää asioiden taustoja, verrata eri asiantuntijoiden käsityksiä tietystä asiasta tai saada hetkessä käännöksen esimerkiksi venäjänkielisestä artikkelista.

Aikuiset, jotka haluavat jatkaa tai täydentää opintojaan voivat tehdä sen suurelta osin kotonaan etäopiskeluna. Televisio ja radio lähettävät yöllä opetusohjelmia, jotka opiskelijan omat video- ja ääninauhurit tallentavat sopivana ajankohtana käytettäväksi.

Opetusteknologinen optimisti näkee tämän kehityssuunnan todellisena. Mikäli uusi tietoyhteiskunta onnistuu saavuttamaan korkean taloudellisen hyvinvoinnin, tähän voidaankin päästä.

Muuttuvissa olosuhteissa tietynhetkinen tieto on yhä useammin luonteeltaan kertakäyttötietoa. Koulutuksessa on kuitenkin tietoaineksen muistaminen ollut perinteisesti oppimisen tärkeä kriteeri. Uudessa tietoyhteiskunnassa mekaaninen muistaminen voidaan jättää ainakin osittain tietokoneiden tehtäväksi. Silloin voidaan esimerkiksi aikuiskoulutuksessa opiskella enemmänkin näiden tietovarastojen tarkoituksenmukaista käyttöä, luovaa tietojen yhdistämistä sekä niitä yleisiä periaatteita ja lainalaisuuksia, joiden varassa ongelmia voidaan ratkaista ja todellisuutta ymmärtää ja säädellä. Tällä hetkellä tiedämme kuitenkin varsin vähän uuden teknologian käyttömahdollisuuksista koulutuksessa, sen hyvistä puolista ja mahdollisista vaaroista.

Opetusteknologia on ollut ja tulee aina olemaan vain oppimisen apuväline. Atk-valmiuksia voidaan oppia. Tietojen käsittelytaito ja lukutaito voidaan rinnastaa, mutta lukutaitokaan sinänsä ei ole taannut oppimista.

Hawkridgen ennusteen mukaan tietoteknologiaa myyvät yritykset saavat asiakkaikseen ensin teollisuuden ja kaupan, siirtyvät sitten maatalouden, kotitalouksien ja hallinnon alueille ja viimeksi koulutuksen alueille. - Vaikuttaa todennäköiseltä, että koulutuksessa kaikilla tasoilla, myös aikuiskoulutuksessa, pyritään joka tapauksessa hankkimaan tietojenkäsittelyn perusvalmiuksia ja esimerkiksi täydennyskoulutuksessa opiskellaan ainakin rajattuja tietoteknologian sovellutuksia (esim. jonkin tiedoston käyttöä).

\section{Korkeakoulut ja aikuiskoulutus}

Yhteiskunnan muuttuessa ihmisiä vapautuu perinteisestä työelämästä etsimään jäsennystä elämälleen uusissa olosuhteissa. Korkeakoulut eivät voi tässä tilanteessa jäädä tapahtumien 
ulkopuolelle; juuri niillä on hallussaan ajankohtainen tieto, jolla muutosta pystytään jäsentyneemmin hallitsemaan.

Elinikäisen oppimisen periaatteen toteutuminen korkeakouluissa tulee lähentämään korkeakouluja ja muuta yhteiskuntaa. Tavoitteena on tässä vaiheessa ollut tarjota aikuisväestölle toisaalta koulupohjasta ja ammatista riippumatta mahdollisuus opiskella korkeakoulututkintoihin liittyviä opintojaksoja ja -kokonaisuuksia ja avata väyliä tutkintojen suorittamiseen sekä toisaalta: tarjota tietyn ammatin vaativia laaja-alaisia tai yhteen tieteenalaan syventäviä erikoisopintoja. Useissa tapauksissa täydennyskoulutuksen tavoitteena on välillinen tai välitön työllistäminen. Aikuiskoulutuksen, esimerkiksi korkeakoulujen täydennyskoulutuksen, tehtävänä on vastata sekä yhteiskunnan tietynhetkisiin koulutustarpeisiin että pystyä ennakoimaan tulevia tarpeita. Mielestäni on tärkeää, että eri ammattialojen tietoreviirejä pyritään koulutuksessa murtamaan. Se edellyttää eri tieteenalojen ennakkoluulotonta yhteistyötä sekä tutkimuksen että koulutuksen alueilla. Tämä koskee yhtä hyvin perus-, jatko- kuin täydennyskoulutustakin.

Korkeakoulujen täydennyskoulutuksessa voidaan entistä voimakkaammin etsiä uusia tiedon yhdistämismahdollisuuksia. On odotettavissa, että monien nykyisten työtehtävien tilalle on syntymässä uusia. Työelämän muutostilanteissa saattaa olla järkevämpää järjestää esimerkiksi fyysikoille yrittäjäkoulutusta kuin pelkästään lisätä ja ylläpitää heidän erikoisalansa tietämystä.

Useimpiin maamme korkeakouluihin on perustettu erityinen täydennyskoulutuskeskus vastaamaan aikuiskoulutuksen uusiin haasteisiin. Mm. Helsingin yliopiston Lahden tutkimus- ja koulutuskeskuksen tehtävänä on järjestää tiedekuntien ja laitosten hyväksymällä tavalla korkeakouluopetusta lähinnä avoimen korkeakoulun periaatteen mukaisesti.

Korkeakoulujen perimmäiset tehtävät, tutkimus ja opetus, ja aikuiskoulutuksen uudet tehtävät eivät ole keskenään ristiriidassa. Myös korkeakoulujen aikuiskoulutus eri muodoissaan rakentuu tieteellisen tiedon varaan.

\section{Aikuiskoulutuksen tutkimus}

Aikuiskoulutuksen tutkimusalueina voidaan mainita mm. koulutuksen vaikuttavuuden tutkiminen, opetus- ja oppimisprosessit, ihmisen elämänkaarta koskeva tutkimus sekä aikuisen ja hänen ympäristönsä välisen vuorovaikutuksen tutkiminen.

Jos koulutus nähdään kapeasti vain pedagogisena toimintana, aikuiskoulutuksen tutkimus kiinnittäisi huomiota erityisesti opetus- ja oppimisprosesseihin. Tämä on luonnollisesti keskeistä ja tärkeää. Yhtä tärkeää on kuitenkin pyrkiä tutkimuksen avulla ymmärtämään laajemmin muuttuvaa yhteiskuntaa ja ihmistä tämän muutosprosessin osana. Erityisen kes"keiseksi käsitteeksi tutkimuksessa nousee juuri muutoksen käsite. Yliopistoissa jokainen tieteenala omalta osaltaan vastaa tämän todellisuuskuvan rakentamisesta. Tieteenalojen yhteistyön tärkeä tehtävä on muodostaa näistä osista mahdollisimman ehyt kokonaisuus.

\section{Lähteet}

Costello, N. \& Richardson, M. (eds.). 1982. The Continuing Education for the Post-Industrial Society. The Open University Press, Milton Keynes.

Hawkridge, D. 1983. New Information Technology in Education. Croom Helm, London \& Canberra.

Mezirow, J. 1981. "A Critical Theory of Adult Learning and Education". Adult Education 32, $3-24$. 